\title{
Predictive Value of MR-proADM in the Risk Stratification of COVID-19 Patients Assessed at the Triage of the Emergency Department
}

Marilena Minieri

Department of Experimental Medicine, University of Rome Tor Vergata- Unit of Laboratory Medicine, Tor Vergat University Hospital

Vito N. Di Lecce

Emergency Medicine, Emergency Department, Tor Vergata University Hospital, Rome, Italy

Maria Stella Lia

Unit of Laboratory Medicine, Tor Vergata University Hospital, Rome, Italy

Massimo Maurici

Department of Biomedicine and PRevention, University of Rome Tor Vergata, Rome, Italy

Francesca Leonardis

Department of Surgical Science, University of Rome Tor Vergata- Intensive Care Unit, Emergency Department, Tor Vergata

University Hospital, Rome, Italy

Susanna Longo

Department of Systems Medicine, University of Rome Tor Vergata Rome, Emergency Medicine, Emergency Department, Tor Vergata University Hospital, Rome Italy

Luca Colangeli

Department of Systems Medicine, University of Rome Tor Vergata, Emergency Medicine, Emergency Department, Tor Vergata University Hospital, Rome, Italy

Carla Paganelli

Emergency Room, Emergency Department, Tor Vergata University Hospital, Rome, Italy

Stefania Levantesi

Department of Systems Medicine, University of Rome Tor Vergata, Emergency Medicine, Emergency Department, Tor Vergata University Hospital, Rome, Italy

Alessandro Terrinoni

Department of Experimental Medicine, University of Rome Tor Vergata, Rome, Italy

Vincenzo Malagnino

Infectious Disease Unit, Department of Assistential Integrated Processes, Tor Vergata Huniversity Hospital, Rome, Italy

\section{Domenico Junior Brunetti}

Department of Clinical Science and Translational Medicine, University of Rome Tor Vergata - Anaesthesia and Intensive Care Unit, Emergency Department, Tor Vergata University Hospital, Rome, Italy https://orcid.org/0000-0002-5631-4071

Alfredo Giovannelli

Unit of Laboratory Medicine, Tor Vergata University Hospital, Rome, Italy

Massimo Pieri

Department of Experimental Medicine, University of Rome Tor Vergata, Rome, Italy

\section{Marco Ciotti}

Department of Laboratory Medicine, Virologi Unit, Tor Vergata University Hospital, Rome, Italy

\section{Cartesio D’Agostini}

Department of Laboratory Medicine, University of Rome Tor Vergata, Laboratory of Clinical Microbiology, Policlinico Tor Vergata, Roma, Italy

\section{Mariachiara Gabriele}

Department of Experimental Medicine, University of Rome Tor Vergata, Unit of Respiratory Medicine, Tor Vergata University Hospital, Rome, Italy 


\section{Sergio Bernardini}

Department of Experimental Medicine, University of Rome Tor Vergata, Unit of Laboratory Medicine, Tor Vergata University Hospital, Rome, Italy

Jacopo Maria Legramante ( $\sim$ legraman@uniroma2.it)

University of Rome TorVergata - Emergency Medicine https://orcid.org/0000-0001-9762-9902

\section{Research}

Keywords: Emergency department, Triage, COVID-19 biomarkers, MR-proadrenomedullin

Posted Date: November 19th, 2021

DOI: https://doi.org/10.21203/rs.3.rs-1077358/v1

License: (c) (i) This work is licensed under a Creative Commons Attribution 4.0 International License. Read Full License 


\section{Abstract \\ Background}

In the last two pandemic years, the Emergency Departments (ED) have been overrun with COVID-19 suspicious patients, creating a pressing need to optimize resources through risk stratification for those patients. For this reason, the assessment of prognostic tools and biomarkers have been necessary. Some dataon the role played by laboratory biomarkers in the early risk stratification of COVID19 patients have been recently published. The aim of this study is to assess the potential role of the new biomarker mid-regional proadrenomedullim (MR-proADM) in stratifying the in-hospital mortality risk of COVID-19 patients at the triage in order to help the emergency physician in the decision-making process. A further goal of the present study is to evaluate whether MR-proADM together with other biochemical markers could play a key role in assessing the correct care level of these patients by predicting who could need intensive care and ventilation.

\section{Methods}

Data from 321 consecutive patients admitted to the triage of the emergency department with a COVID-19 infection were analyzed. Epidemiological, demographic, clinical, laboratory, and outcome data were assessed. C-reactive protein (CRP), procalcitonin (PCT), lactate dehydrogenase (LDH), d-dimer and MR-proADM blood levels were also evaluated.

\section{Results}

All the biomarkers evaluated showed significant increased values at admission in the emergency department in non-survivorsvs survivors as well in ventilated as compared to non-ventilated patients. Moreover, all the biomarkers analyzed showed animportant role in predicting mortality, need of invasive mechanical ventilation (IMV) and non-invasive mechanical ventilation (NIMV) in patients admitted at the emergency department with COVID-19 infection as analyzed by the univariate Cox regression analysis. Pooling together both clinical and laboratory variables in a multivariate analysis, all biomarkers, except for PCT, seem to play a significant role in the mortality risk stratification at admission in the emergency department. Similarly, an increase of MR-proADM level at ED admission resulted independently associated with a threefold times higher risk of IMV. LDH showed a smaller but still significant power. CRP only showed a significant predictive value for the need of NIMV. In patients COVID-19 positive, MR-proADM assessed at the admission in the triage showed a good discriminative performance both for in-hospital mortality $(A U C), 85)$ and for prediction of IMV (AUC 0,81), whereas it was less effective for NIMV prediction (AUC 0,71). ROC curves and AUC resulted significantly greater for MR-proADM as compared to other laboratory biomarkers for the primary endpoint, i.e. in-hospital mortality, with the exception of CRP.

\section{Conclusion}

This study shows that MR-proADM seems to be particularly effective for early predicting mortality and the need of ventilation in COVID-19 patients admitted to the emergency department.

\section{Introduction}

The severe acute respiratory syndrome coronavirus 2 (SARS-CoV-2) pandemic has spread worldwide and reached catastrophic proportions in the last two years. The SARS-CoV-2 infection has been named coronavirus disease 2019 (COVID-19). The World Health Organization (WHO) declared the SARS-CoV-2 infection as 'Public Health Emergency of International Concern' due to its rapid transmission among humans. After two years of the pandemic, there have been more than 230 million cases worldwide and nearly 5 million deaths. The SARS-CoV-2can present different symptoms and levels of severity including asymptomatic infection, mild upper respiratory tract illness, and severe viral pneumonia with respiratory failure [1].

During the pandemic, the admissions to the hospitals greatly increased thus stressing out the capacity of public health systems and resulting in a high mortality rate. This situation has been complicated further due to nonspecific clinical features of COVID-19 
pneumonia making it difficult to distinguish from other causes of severe pneumonia [1].

The lack of immediate results from the current microbiological tests to confirm COVID-19, coupled with the reported suboptimal sensitivity of swab tests by real-time reverse transcription-polymerase chain reaction (RT-PCR) assays, made the situation worse [2]. As a result, the emergency departments have been overrun with suspicious COVID-19 patients, creating a pressing need to optimize resources through risk stratification for those patients already upon entering the triage.Since predicting the course of this disease at symptom onset is difficult and very often clinical conditions tends to worsen abruptly, prognostic tools and/orbiochemical markers have been fundamental to address patients through the right clinical pathway in the emergency department

(ED).However,althoughseveral laboratory biomarkers have been so far identified to diagnose more rapidly COVID-19 pneumonia,to date, there is no data on biomarkers with high specificity and sensibility able to early stratify the mortality risk of patients affected by viralpneumonia [3].

C-reactive protein (CRP) has been one of the most used biomarkers to assessthe evolution of COVID-19 inflammatory processes, even though its use is limited by a low sensitivity for community-acquired pneumonia (CAP). While a high CRP value (>100 mg/L) can indicate a severe bacterial infection, lower values are common in both viral infections and noninfectious diseases [4].

Another biomarker evaluated in COVID-19 patients has been the procalcitonin (PCT), since it has an important role in detecting a bacterial superinfection to manage antibiotic therapy [5]. As known, PCT can predict microbial etiology in pneumonia [6]. On the other hand, in patients with a high PSI (classes III-V), PCT has proven to be a good prognostic marker rather than a diagnostic marker [7].

Procalcitonin, CRP and white blood cell count have shown to be significantly higher in CAP patients with a typical bacterial etiology as compared to cases in which the pathogen was represented by an atypical bacterium or by a virus [8].

Mid-regional proadrenomedullin (MR-proADM), a more stable fragment of the rapidly degrading active adrenomedullin (ADM) peptide, has been proven a promising biomarker, particularly effective in detecting endothelial dysfunction thus predicting severity and long-term adverse outcomes in CAP. In fact, Christ-Crain et al. [9]demonstrated that the level of MR-proADM, in contrast to CRP levels and leukocytes, increased according to CAP severity.Valenzuela Sanchez et al. [10] reported that MR-proADMwas able to predict unfavorable outcomes in patients with influenza virus-induced pneumonia.Furthermore, MR-proADMis able to stratify the clinical risk in patients affected by CAP [11]. It has also been reported that MR-proADMobtained within 6 hours of arrival at the hospital has considerable prognostic value, independently of the causal agent of CAP and, if associated with PSI and CURB-65, it improves prognostic accuracy $[11,12]$.

Interestingly, when the microcirculatory integrity is deteriorating causing the capillary leak, an alteration of the endothelium barrier function can occur, as happens during sepsis. It has been demonstrated that in these conditions MR-proADM plasma concentrations tend to increase [13].

Accordingly, Hupf et al. [14] have recently reported significantly higher adrenomedullin RNA blood expression in patients with severe COVID-19 vs. patients with a mild disease.

In this context, Li et al. (15) hypothesized that the integrity of the epithelial-endothelial barrier was severely interrupted in critical patients with COVID-19-related pneumonia thus introducing the concept of "viral sepsis". Confirming this pathogenetic mechanism, recent studies have shown that proinflammatory cytokines and chemokines such as tumor necrosis factor-a (TNF-a) and interleukin6(IL-6) increased in COVID-19 [16,17] and that this cytokine storm might play a key role in the evolution of SARS-CoV-2 infection [18].

Despite recent studies have demonstrated a predictive value of MR-proADM in patients with COVID-19-related pneumonia [19-21], no data are actually available about risk stratification of patients with a suspected SARS-CoV-2 infection at the triage in the emergency department.

Therefore, the aim of this study is to assess the role of MR-proADM,in comparison to other biochemical markers, in stratifying the inhospital mortality risk of COVID-19 patients admitted at the triage in order to help the emergency physician in the decision concerning the rule-in or rule-out of these patients. A further goal of the present study is to evaluate whether the laboratory biomarkers can play a key role in predicting also the correct care level of these patients thus contributing to optimize the hospital resources. 


\section{Materials And Methods \\ Study design}

The present study has an observational, retrospective single-center design. Data from 321 consecutive patients admitted to the Emergency Department of the University Hospital Tor Vergata (Rome, Italy) from Aprilto December 2020 with a confirmedCOVID-19 infectionwere analyzed. A diagnosis of COVID-19 was made by a positive real-time reverse transcription polymerase chain reaction (RT-PCR) taken from nasopharyngeal swabs and through radiological imaging, where indicated, in accordance with WHO interim guidelines.

Adult patients aged more than 18 yearswith a positive swab test were enrolled.

The epidemiological, demographic and clinicaldata were extracted from the electronic clinical records (Tab. 1).

Either chest X-rays or computed tomography scans were performed, depending on the physician's clinical assessment, and these were further reviewed by the emergency department's radiologist. When necessary, analyses of blood culture, sputum, urine, bronchial aspirate, and/or bronchoalveolar samples were also assessed.

The final diagnosis was considered as that provided by the emergency department physician. A patient follow-up was performed up to 45 days.

The study was approved by the Local Ethics Committee (approval number $87 / 20$ ) and was performed in accordance with the Declaration of Helsinki. Written informed consent was waived due to the rapid emergence of this infectious disease.

\section{Blood sample collection}

All baseline blood samples were immediately collected immediately at the triage admission. For serum and plasma specimens, blood samples were rapidly centrifuged upon arrival to the laboratory at $4500 \mathrm{xg}$ for 5 minutes.

Blood examinations were for mid-regional proadrenomedullin (MR-proADM), C-reactive protein (CRP), procalcitonin (PCT), d-dimer, lactate dehydrogenase (LDH).

CRP (normality value $<5 \mathrm{mg} / \mathrm{L}$ ) and LDH ( $<220 \mathrm{IU} / \mathrm{L}$ ) levels were measured in serum using an Abbott ARCHITECT c16000 (Abbott, North Chicago, USA) clinical chemistry analyzer. PCT (normalityvalue $<0.5 \mathrm{ng} / \mathrm{mL}$ ) was detected in serum with a BRAHMS PCT chemiluminescentmicroparticle immunoassay (CMIA) by Abbott ARCHITECT i2000SR instrument. MR-proADM (normality value $<0.55 \mathrm{nmol} / \mathrm{L}$ ) was measured using a time-resolved amplified cryptate emission assay on EDTA plasma samples (TRACE BRAHMS MR-proADMKryptor, BRAHMS AG, Hennigsdorf, Germany).D-dimer values were obtained by an ACL TOP 700 Instrument by Instrumentation Laboratory Company (Werfen, Bedford, MA, USA).

\section{Statistical analysis}

The primary endpoint was the overall in-hospital mortality; the secondary endpoints were the need of NIMV and IMV.

Continuous variables were expressed as mean (standard deviation) or median (interquartile ranges), according to data distribution, and were compared using the Student's t-test or the Mann-Whitney U test, when appropriate; categorical variables were expressed as counts and percentages and compared using the Chi-square or Fisher's exact tests, as appropriate.

Associations between candidate variables and endpointswere assessed using both univariate and multivariate Cox regression analyses, and hazard ratios were calculated. We have evaluated survivors compared with non-survivors and patients who needed ventilation (both invasive and non-invasive) compared with patients without ventilation.

The discriminatory power of the analyzed variables for predicting mortality was tested by means of a receiver operating characteristic (ROC) curve analysis with area under the ROC curve (AUC) determination.

For the regression analysis, variables were dichotomized according to cut-off values derived during the data analysis for this study, using the Youden index arising from the ROC curve analysis.

Page 5/22 
For each biomarker, sensitivity, specificity, negative and positive predictive values (NPV, PPV), negative and positive likelihood ratio (LR-, LR+), and odds ratio with $\mathrm{Cl} 95 \%$ were also reported for mortality, IMV and NIMV(Tab. 5).

Kaplan-Meier curves were created to estimate the overall survival and compared using the log-rank test.

All analyses were performed with SPSS software. Tests were considered statistically significant if they yielded two-tailed $p$ values $<0.05$. For the multivariate analysis, we used variables resulting statistically significant in the univariate analysis.

\section{Results}

The study population ranged from 321 to 284 patients according to the different analysisdue to missed biomarkers data and one patient who died after 45 days as detailed in Table 3.

The demographic and clinical characteristics of the study populationare summarized in Table 1. The patient population had a mean age of $63 \pm 14,7$ years. Hypertension (40,8\%), cardiovascular diseases $(17,1 \%)$ and diabetes $(13,1 \%)$ represented the most frequent comorbidities(Tab. 1).

Among the comorbidities reported, obesity did not show significant differences between survivors and non-survivors, whereas malignancy showed a statistical level close to the significance. All the other comorbidities showed a significant difference between the two groups considered. Evaluating the secondary outcomes, cardiovascular disease and malignancy did not show significant differences between IMV and no-IMV, whereas all the other comorbidities showed a significant difference. For the last group of patients, only hypertension and renal disease showed significant differences between NIMV and no-NIMV patients.

All the biomarkers evaluated just after triage showed increased values in non-survivors as compared to survivors as well as in IMV and NIMV compared to no-IMV and no-NIMVreaching always a statistically significant level (Tab.2).

Table 3 shows the results of the univariate Cox regression analysis performed to investigate the possible predictive role of clinical and demographic characteristics in patients with suspected COVID-19 infections. In addition, obesity does not seem to predict 45 days mortality, whereas malignancy showed a statistical level close to the significance in patients evaluated at the triage in the Emergency Department. All the other clinical features have shown significant odds ratio value to predict mortality in this group of patients.

Concerning the possible role in predicting need of IMVwithin 28 days in these patients, all the clinical features reached the statistical significance except for cardiovascular disease and malignancy, whereas only hypertension and renal diseases showed a significantodds ratio value for NIMV within 28 days (Tab. 3 ).

All the biomarkers analyzed showed a significant role in predicting mortality, need of IMV and NIMV in patients admitted at the ED with COVID-19 infection as analyzed by the univariate Cox regression analysis (Tab. 3).

Pooling together bothclinical and laboratory variables in a multivariate analysis and considering the whole observation period (mortality at 45 days, IMV and NIMV at 28 days), all biomarkers, except PCT, seem to play a key role in the mortality risk stratification at the admission in the emergency department (Tab. 4). In fact, patients with avalue of MR-proADM higher than the cut-off value of 1.105 show an increase of mortality of almost three times(OR 2,97, IC 1,7-5,28);also CRP levels were independently associated with a higher risk of in-hospital mortality in patients with COVID 19 (OR 2,85, IC 1,73-4,69).Similarly, an increase in the admission MRproADM level was independently associated with almost three times (OR 2,83, IC 1,49-5,36) higher risk of the need of IMV as well as for LDH which showed a smaller but still significant risk (OR 2,18, IC 1,33-3,57). Only CRP showed a significant predictive value (OR 2, IC 1-3,7) for the need of NIMV.

In COVID-19 patients,MR-proADM assessed at the ER admission showed a good discrimination performance both for in-hospital mortality (AUC 0,85) and for prediction of IMV (AUC 0,81), whereas it was less effective for NIMV prediction (AUC 0,71) with the optimal cut-off of 1,105 as obtained with the Youden index. ROC curves and AUC resulted significantly greater for MR-proADM as compared to the other biomarkers for the primary endpoint, i.e. in-hospital mortality,except for CRP (Tab. 5 and Fig. 1). 
In particular, MR-proADM showed the better PPV (65\%) and especially NPV (87\%) in predicting mortality as well as for IMV and NIMV regarding NPV (both $88 \%$ ) as compared to the other biomarkers with only CRP that showed similar values (Tab. 5).

The good discrimination performance of MR-proADM for the primary and secondary endpoint is also showed by the survival curves (Fig. 2). In fact, a higher survival rate and a reduced mechanical ventilation risk were evident for patients with values less than $1,05 \mathrm{nmol} / \mathrm{L}$ at the admission in the ED.

Similar results have been found for CRP (Fig. 2), whereas the performance was lower for PCT, d-dimer and LDH, as shown in Figure 3 , where it is evident a poor discrimination power.

\section{Discussion}

The severe acute respiratory syndrome coronavirus 2 (SARS-CoV-2) infection has heavily affected the worldwide population in the last two years. Although most patients infected by SARS-CoV-2 had only a mild illness, about $5 \%$ of them suffered severe lung injury or even multiorgan dysfunction [22], requiring admission at intensive care unit (ICU).

Consequently, emergency departments have seen a dramatic increase in their workload, triggering the need to optimize resources and the decision to hospitalize only seriously ill patients, in order to face the more adequate care level.

The utilization of biomarkers at the admission to the emergency department to quickly stratify risksfor patients with pneumonia and other diseases has been largely reported [12,23,24]. We have shown, in previous studies, that MR-proADM is effective in risk stratification for patients affected by community-acquired pneumonia (CAP), as well as in promptly determining the appropriate level of care in the emergency department $[11,25]$.

To our knowledge, this is the first study focused on the ability of new, as MR-proADM, and traditional biomarkers in the risk stratification of patients with COVID-19 infections at the emergency department admission.

Previous studies performed with a smaller number of patients have reported that MR-pro ADM can play a role in predicting outcome in already hospitalized patients affected by COVID-19-related pneumonia $[19,20]$.

In particular, our group has recently reported that MR-proADM seems to represent the most powerful biomarker for predicting death in critical patients at ICU, where the outcome can happen earlier, within one week, thus representing a good predictor for disposition of patients from emergency department to ICU [21].

In line with these previous studies, the median admission levels of all biomarkers checked in our studies showed significant higher values for all the endpoints considered, i.e. non-survivors vs survivors, IMV vs no-IMV and NIMV vs no-NIMV. This result suggests that these biomarkers might play a predictive role in the early risk stratification of patients with COVID-19 infections.In fact, all the biomarkers considered showed a significant predictive value for the endpoints considered when analyzed with a univariate analysis.

Considering the possible confounding effect of the demographic and clinical features of patients, a multivariate analysis was performed pooling together both the clinical characteristics and the biomarkers assessed in the study. MR-proADM showed the best predictive value for the primary endpoints and for the need of IMV, whereas did not show significant predictive role for the need of NIMV.

In particular, it is notable that MR-proADM showed the best negative predictive value for all the endpoints considered thus giving a relevant support to the emergency physician in the eventual decision of the patient rule-out or rule-in and of the adequate clinical setting of patients affected by COVID-19 since it is able to predict also the possibility of ventilation need. This relevant information might greatly contribute to optimize the hospital resources and to hasten the decision-making process of the emergency physician.

The great power of MR-proADM in the mortality risk stratification of COVID-19 patients has been further confirmed by the analysis of the ROC curves, which showed a significant greater AUC as compared to the other biomarkers. Similarly, the survival curves showed a primary role of MR-proADM as predictive factor in patients affected by COVID-19 in the emergency department. 
Our novel data are in line with previous studies in which the predictive role of MR-proADMhas been evaluated in hospitalized COVID19 patients [19-21].

Some differences among present and previous studies need to be highlighted. First, the clinical setting. In fact, in previous studies only critical patients admitted in the hospital wards have been enrolled. Our study, instead, have been primarily focused on patients admitted to the emergency department and therefore with different degrees of impairment ranging from asymptomatic to critical conditions. In these populations, the goal is to predict the trajectory of the illness at the symptoms onset and very often this is not easy.

The second important aspect of our study was the number of patients enrolled that was considerably greateras compared to previous studies.

Our data are also in line with previous studies in which the predictive value of biomarkers was tested in patients affected by CAP. Infact, while MR-proADM has been considered a useful tool for risk stratification in patients affected by bacterial pneumonia $[9,11,12]$, PCT proved to be less effective in predicting death and it was therefore considered as a useful diagnostic tool for tailoring antibiotic therapy $[9,26,27]$.

CRP is usually considered as a non-specific marker of acute inflammation that may possibly be influenced by several other factors $[9,27,28]$.

The results of our novel study emphasize the role of biomarkers as a useful tool for emergency physicians in the early risk stratification of patients presenting to the ED, even in the age of COVID-19. Diagnostic and predictive value is likely to increase only after the most effective combination of scores and biomarkers has been established, or even by utilizing a panel of biomarkers [2931]. For these reasons, it is important to know how biomarkers behave in response to defined diseases such as SARS-CoV-2.

The limit of our study is that patients were recruited in only one hospital.Therefore, it would be desirable to extend the study to multiple centers to increase the number of enrolled patients, in order to confirm our results.

\section{Conclusions}

This study, which to our knowledge is the first to evaluate the behavior of the MR-proADM compared to traditional biomarkers in COVID-19 patients at the admission in the ED, shows that all the biomarkers utilized can help the physician in the decisions making process. However,MR-proADM seems to represent the most powerful biomarker for predicting mortality and the need of ventilation in patients admitted at the emergency department. This is particularly useful for helping the emergency physician in the rule-in or ruleout of COVID-19 patients.Furthermore, this study can help in deciding the adequate clinical setting according to the possible need of ventilation thus contributing to optimize the hospital resources.

It is evident, however, that biomarkers will always oversimplify the interpretation of important variables and they complement, rather than supersede, a clinician judgment and/or validated severity scores.

In conclusion, MR-proADM appears to be particularly effective, among other biomarkers, in the risk stratification for COVID-19 patients admitted to the emergency department thus helping the making decision process of emergency physician.

\section{List Of Abbreviations}

AUC: area under the ROC curve

CAP: community-acquired pneumonia

CMIA: chemiluminescentmicroparticle immunoassay

COVID-19: coronavirus disease 2019

CRP: C-reactive protein

Page $8 / 22$ 
ED: emergency department

ICU: intensive care unit

IL6: interleukin-6 (IL-6)

IMV: invasive mechanical ventilation

LDH: lactate dehydrogenase

MR-proADM: mid-regional proadrenomedullin

NIMV: noninvasive mechanical ventilation

PCT: procalcitonin

PSI: pneumonia severity index

ROC: receiver operating characteristic curve

RT-PCR: real-time reverse transcription-polymerase chain reaction

SARS-CoV-2: severe acute respiratory syndrome coronavirus 2

TNF-a: tumor necrosis factor-a

WHO: World Health Organization

\section{Declarations}

Conflicts of Interest:We declare no competing interests.

Author Contributions: All the authors contributed to study conception and design, and analysis and interpretation of the data.

Funding: Not applicable

Acknowledgments:The authors wish to thank Loreta D'Amico and AnnaritaCococcia for their valuable technical assistance and all patients and their families involved in the study.

Institutional Review Board Statement:The study was approved by the Local Ethics Committee and was performed in accordance with the Declaration of Helsinki.

Informed Consent Statement:Not applicable

\section{References}

1. Zhao D, Yao F, Wang L, Zheng L, Gao Y, Ye J, et al.A comparative study on the clinical features of COVID-19 pneumonia to other pneumonias. Clin Infect Dis. 2020;71(15). https://doi.org/10.1093/cid/ciaa247.

2. Xie X, Zhong Z, Zhao W, Zheng C, Wang F, Liu J. Chest CT for typical 2019-nCoV pneumonia: Relationship to negative RT-PCR testing. Radiology.2020;296(2). https://doi.org/10.1148/radiol.2020200343.

3. Xie J, Tong Z, Guan X, Du B, Qiu H, Slutsky AS. Critical care crisis and some recommendations during the COVID-19 epidemic in China. Intensive Care Med. 2020;46(5).https://doi.org/10.1007/s00134-020-05979-7.

4. Melbye, $\mathrm{H}$ and Stocks, N. Point of care testing for C-reactive protein: a new path for Australian GPs?. Australian Family Physician. 2006;35(7):513-517.

5. Jin M, Khan Al. Procalcitonin: Uses in the clinical laboratory for the diagnosis of sepsis. Lab Med. 2010;41(3). https://doi.org/10.1309/LMQ2GRR4QLFKHCH9. 
6. Hedlund J, Hansson L-O. Procalcitonin and C-reactive protein levels in community-acquired pneumonia: correlation with etiology and erognosis. Infection. 2000;28(2). https://doi.org/10.1007/s150100050049.

7. Masiá M, Gutiérrez F, Shum C, Padilla S, Navarro JC, Flores E, et al. Usefulness of procalcitonin levels in community-acquired pneumonia according to the patients outcome research team pneumonia severity index. Chest. 2005;128(4). https://doi.org/10.1378/chest.128.4.2223.

8. Krüger S, Ewig S, Papassotiriou J, Kunde J, Marre R, von Baum H, et al. Inflammatory parameters predict etiologic patterns but do not allow for individual prediction of etiology in patients with CAP: results from the German competence network CAPNETZ. Respir Res. 2009;10(1). https://doi.org/10.1186/1465-9921-10-65.

9. Christ-Crain M, Morgenthaler NG, Stolz D, Müller C, Bingisser R, Harbath S, et al. Pro-adrenomedullin to predict severity and outcome in community-acquired pneumonia [ISRCTN04176397]. Crit Care. 2006;10(3). https://doi.org/10.1186/cc495510.

10. Valenzuela Sanchez F, Valenzuela Mendez B, Rodríguez Gutierrez JF, Bohollo de Austria R, Rubio Quiñones J, Puget Martínez L, et al. Initial levels of mr-proadrenomedullin: a predictor of severity in patients with influenza A virus pneumonia. Intensive Care Med Exp. 2015;3(1). https://doi.org/10.1186/2197-425X-3-S1-A832.

11. Legramante JM, Mastropasqua M, Susi B, Porzio O, Mazza M, Agrippino GM, et al. Prognostic performance of MR-proadrenomedullin in patients with community acquired pneumonia in the Emergency Department compared to clinical severity scores PSI and CURB. PLoSOne.2017;12(11).https://doi.org/10.1371/journal.pone.0187702.

12. Bello S, Lasierra AB, Mincholé E, Fandos S, Ruiz MA, Vera E, et al. Prognostic power of proadrenomedullin in communityacquired pneumonia is independent of aetiology. EurRespir J. 2012;39(5).https://doi.org/10.1183/09031936.00080411.

13. Temmesfeld-Wollbruck B, Hocke AC, Suttorp N, Hippenstiel S. Adrenomedullin and endothelial barrier function. ThrombHaemos. 2007;98(5). https://doi.org/10.1160/th07-02-0128.

14. Hupf J, Mustroph J, Hanses F, Even K, Maier LS, Jungbauer CG. RNA-expression of adrenomedullinis increased in patients with severe COVID-19. Critical Care 2020; 24: 527.https://doi.org/10.1186/s13054-020-03246-1

15. Li H, Liu L, Zhang D, Xu J, Dai H, Tang N, Su X, Cao B. SARS-CoV-2 and viral sepsis: observations and hypotheses. Lancet. 2020;395(10235). https://doi.org/10.1016/S0140-6736(20)30920-X.

16. Huang C, Wang Y, Li X, Ren L, Zhao J, Hu Y. Clinical features of patients infected with 2019 novel coronavirus in Wuhan, China. Lancet.2020;395(10223). https://doi.org/10.1016/S0140-6736(20)30183-5.

17. Liu J, Li S, Liu J, Liang B, Wang X, Wang H, et al. Longitudinal characteristics of lymphocyte responses and cytokine profiles in the peripheral blood ofSARS-CoV-2 infected patients. E Bio Medicine. 2020; 55. https://doi.org/10.1016/j.ebiom.2020.102763.

18. Iwasaki A, Pillai PS. Innate immunity to influenza virus infection. Nat Rev Immunol.2014;14(5).https://doi.org/10.1038/nri3665.

19. Gregoriano C, Koch D, Kutz A, Haubitz S, Conen A, Bernasconi L, Hammerer-Lercher A, Saeed K, Mueller B, Schuetz P. The vasoactive peptide MR-pro-adrenomedullin in COVID-19 patients: an observational study. ClinChem Lab Med. $2021 \mathrm{Jan}$ 8:cclm2020-1295. doi: 10.1515/cclm-2020-1295.

20. Spoto S, Agrò FE, Sambuco F, Travaglino F, Valeriani E, Fogolari M, Mangiacapra F, Costantino S, Ciccozzi M, Angeletti S. High value of mid-regional proadrenomedullin in COVID-19: A marker of widespread endothelial damage, disease severity, and mortality. J Med Virol. 2020 Nov 17:10.1002/jmv.26676. doi: 10.1002/jmv.26676. Epub ahead of print. PMID: 33200824; PMCID: PMC7753433.

21. Leonardis F, Minieri M, Lia MS et al. Early predictive value of MR-proADM in critically ill patients with Covid-19: an observational study in the Emergency Department. Journal of Emergency Medicine and Care. 20214 (1): 103.

22. Guan WJ, Ni ZY, Hu Y, Liang W, OuC, He J, et al. Clinical characteristics of coronavirus disease 2019 in China. N Engl J Med. 2020;382(18). https://doi.org/10.1056/NEJMoa2002032.

23. Saeed K, Wilson DC, Bloos F, Schuetz P, van der Does Y, Melander O, et al. The early identification of disease progression in patients with suspected infection presenting to the emergency department: a multi-centre derivation and validation study. Crit Care. 2019;23. https://doi.org/10.1186/s13054-019-2329-5.

24. Cardellini M, Rizza S, Casagranda V, Cardolini I, Ballanti M, Davato F, Porzio O, Canale MP, Legramante JM, Mavillo M, Menghini R, Martelli E, Farcomeni A, Federici M. Soluble ST2 is a biomarker for cardiovascular mortality related to abnormal glucose metabolism in high-risk subjects. ActaDiatelol 2019 Mar; 56 (3): 273-280. doi: 1007/s00592-018-1230-z. Epub 2018 Sep 26. Pubmed PMID: 30259114. 
25. Saeed K, Legramante JM, Angeletti S, Curcio F, Miguens I, Poole S, Tascini C, Sozio E, Del Castillo JG. Mid-regional proadrenomedullinasasupplementarytoolto clinical parameters in cases of suspicionof infection in the emergencydepartment. Expert Rev Med PharmacolSciMar 29:1-8. doi: 10.1080/14737159.2021.1902312. Online ahead of print.PMID: 33736553.

26. Christ-Crain M, Jaccard-Stolz D, Bingisser R, Gencay MM, Huber PR, Tamm M, Muller B. Effect of procalcitonin-guided treatment on antibiotic use and outcome in lower respiratory tract infections: cluster-randomised, single-blinded intervention trial. Lancet. 2004;363.https://doi.org/10.1016/S0140-6736(04)15591-8.

27. Espana PP, Capelastegui A, Mar C, Bilbao A, Quintana JM, Diez R, et al. Performance of pro-adrenomedullinforidentifying adverse outcomes in community-acquired pneumonia. J Infect. 2015;70(5). https://doi.org/ 10.1016/j.jinf.2014.12.003.

28. Luna CM. C-reactive protein in pneumonia: let me try again. Chest. 2004;125(4). https://doi.org/10.1378/chest.125.4.1192.

29. Asai N, Watanabe H, Shiota A, Kato H, Sakanashi D, Hagihara M, et al..Efficacy and accuracy of qSOFA and SOFA scores as prognostic tools for community-acquired and healthcare-associated pneumonia. Int J Infect Dis. 2019 ; 84. https://doi.org/10.1016/j.ijid.2019.04.020.

30. Spoto S, Legramante JM, Minieri M, Fogolari M, Terrinoni A, Valeriani E, et al. How biomarkers can improve pneumonia diagnosis and prognosis: Procalcitonin and MR-proAdrenomedullin. BiomarkMed. 2020; 14 (7). https://doi.org/10.2217/bmm2019-0414.

31. Formica V, Minieri M, Bernardini S, Ciotti M, D’Agostini C, Roselli M, Andreoni M, Morelli C, Parisi G, Federici M, Paganelli C and Legramante JM. Complete blood count might help to identify subjects with high probability of testing positive to SARS-CoV-2. Clinical medicine 2020; 20 (6). DOI: 10.7861/clinmed 2020-0373.

\section{Tables}

Table 1. Demographic and clinical parameters 


\begin{tabular}{|llllllllll} 
Overall & Survivors & $\begin{array}{l}\text { Non- } \\
\text { Surviv }\end{array}$ & $\begin{array}{l}\text { v } \\
\text { value }\end{array}$ & No-IMV & IMV & $\begin{array}{l}\text { P } \\
\text { value }\end{array}$ & $\begin{array}{l}\text { No- } \\
\text { NIMV }\end{array}$ & NIMV & $\begin{array}{l}\text { P } \\
\text { value }\end{array}$ \\
\hline N 321 & $N 224$ & $N 97$ & & $N 234$ & $N 87$ & & N 177 & N 57 &
\end{tabular}

\section{Age}

\begin{tabular}{|c|c|c|c|c|c|c|c|c|c|c|}
\hline Years, mean (SD) & $\begin{array}{l}63.3 \\
(14.7)\end{array}$ & $\begin{array}{l}59.6 \\
(14.6)\end{array}$ & $\begin{array}{l}71.9 \\
(11.2)\end{array}$ & $<0.001$ & $\begin{array}{l}61.4 \\
(15.8)\end{array}$ & $\begin{array}{l}68.6 \\
(9.7)\end{array}$ & $<0.001$ & $\begin{array}{l}59.6 \\
(16.2)\end{array}$ & $\begin{array}{l}67 \\
(12.9)\end{array}$ & 0.002 \\
\hline \multicolumn{11}{|l|}{ Sex } \\
\hline Male, $\quad \mathrm{N}(\%)$ & $\begin{array}{l}215 \\
(67.0)\end{array}$ & $\begin{array}{l}145 \\
(64.7)\end{array}$ & $\begin{array}{l}70 \\
(72.2)\end{array}$ & 0.193 & $\begin{array}{l}146 \\
(62.4)\end{array}$ & $\begin{array}{l}69 \\
(79.3)\end{array}$ & 0.004 & $\begin{array}{l}107 \\
(60.4)\end{array}$ & $\begin{array}{l}39 \\
(68.4)\end{array}$ & 0.28 \\
\hline Female, N (\%) & $\begin{array}{l}106 \\
(33.0)\end{array}$ & 79 (35.3) & $\begin{array}{l}27 \\
(27.8)\end{array}$ & & $\begin{array}{l}88 \\
(37.6)\end{array}$ & $\begin{array}{l}18 \\
(20.7)\end{array}$ & & $\begin{array}{l}70 \\
(39.6)\end{array}$ & $\begin{array}{l}18 \\
(31.6)\end{array}$ & \\
\hline
\end{tabular}

\section{Comorbidities}

\begin{tabular}{|c|c|c|c|c|c|c|c|c|c|c|}
\hline Hypertension, N (\%) & $\begin{array}{l}131 \\
(40.8)\end{array}$ & 70 (31.3) & $\begin{array}{l}61 \\
(62.9)\end{array}$ & $<0.001$ & $\begin{array}{l}81 \\
(34.6)\end{array}$ & $\begin{array}{l}50 \\
(57.5)\end{array}$ & $<0.001$ & $\begin{array}{l}51 \\
(28.8)\end{array}$ & $\begin{array}{l}30 \\
(52.6)\end{array}$ & 0.001 \\
\hline Diabetes, N (\%) & $\begin{array}{l}42 \\
(13.1)\end{array}$ & $19(8.5)$ & $\begin{array}{l}23 \\
(23.7)\end{array}$ & $<0.001$ & $\begin{array}{l}21 \\
(9.0)\end{array}$ & $\begin{array}{l}21 \\
(24.1)\end{array}$ & $<0.001$ & $\begin{array}{l}13 \\
(7.3)\end{array}$ & $\begin{array}{l}8 \\
(14.0)\end{array}$ & 0.124 \\
\hline $\begin{array}{l}\text { Respiratory disease, } \mathrm{N} \\
(\%)\end{array}$ & $28(8.7)$ & $14(6.3)$ & $\begin{array}{l}14 \\
(14.4)\end{array}$ & 0.017 & $\begin{array}{l}16 \\
(6.8)\end{array}$ & $\begin{array}{l}12 \\
(13.8)\end{array}$ & 0.05 & $\begin{array}{l}13 \\
(7.3)\end{array}$ & $\begin{array}{l}3 \\
(5.3)\end{array}$ & 0.588 \\
\hline Malignancy , N (\%) & $19(5.9)$ & $10(4.5)$ & $9(9.3)$ & 0.093 & $\begin{array}{l}11 \\
(4.7)\end{array}$ & $8(9.2)$ & 0.129 & $7(4.0)$ & $\begin{array}{l}4 \\
(7.0)\end{array}$ & 0.342 \\
\hline $\begin{array}{l}\text { Cardiovascular } \\
\text { disease, N (\%) }\end{array}$ & $\begin{array}{l}55 \\
(17.1)\end{array}$ & $27(12.1)$ & $\begin{array}{l}28 \\
(28.9)\end{array}$ & $<0.001$ & $\begin{array}{l}37 \\
(15.8)\end{array}$ & $\begin{array}{l}18 \\
(20.7)\end{array}$ & 0.303 & $\begin{array}{l}26 \\
(14.7)\end{array}$ & $\begin{array}{l}11 \\
(19.3)\end{array}$ & 0.407 \\
\hline Renal disease, N (\%) & $\begin{array}{l}51 \\
(15.9)\end{array}$ & $13(5.8)$ & $\begin{array}{l}38 \\
(39.2)\end{array}$ & $<0.001$ & $\begin{array}{l}17 \\
(7.3)\end{array}$ & $\begin{array}{l}34 \\
(39.1)\end{array}$ & $<0.001$ & $8(4.5)$ & $\begin{array}{l}9 \\
(15.8)\end{array}$ & 0.004 \\
\hline Obesity, N (\%) & $15(4.7)$ & $8(3.6)$ & $7(7.2)$ & 0.155 & $7(3.0)$ & $8(9.2)$ & 0.019 & $7(4.0)$ & $0(0)$ & 0.127 \\
\hline
\end{tabular}

Values expressed in percentages (\%) indicate the proportion of patients within each group for each variable. Data are presented as mean (standard deviation, SD) where specified. The chi-square $(X 2)$ test was used to determine significance between the groups for categorical variables, Student's $t$ test for the variable of age.

IMV: Invasive Mechanical ventilation

NIMV: Non Invasive Mechanical ventilation

Table 2. Biomarkers values at triage admission 


$\begin{array}{llllllllll}\text { Overall } & \text { Survivors } & \begin{array}{l}\text { Non } \\ \text { Surviv }\end{array} & \begin{array}{l}\text { P } \\ \text { value }\end{array} & \begin{array}{l}\text { No- } \\ \text { IMV }\end{array} & \text { IMV } & \begin{array}{l}\text { P } \\ \text { value }\end{array} & \begin{array}{l}\text { No- } \\ \text { NIMV }\end{array} & \text { NIMV } & \begin{array}{l}\text { P } \\ \text { value }\end{array} \\ \text { N } 321 & \text { N } 224 & \text { N } 97 & & \text { N } 234 & \text { N } 87 & & \begin{array}{l}\text { N } \\ 177\end{array} & \text { N } 57 & \end{array}$

\begin{tabular}{|c|c|c|c|c|c|c|c|c|c|c|}
\hline \multirow{2}{*}{$\begin{array}{l}\text { MR-proADM nmol/L } \\
\text { (median, Q1-Q3) }\end{array}$} & 0.90 & 0.75 & 1.46 & \multirow[t]{2}{*}{$<0.001$} & 0.79 & 1.42 & \multirow[t]{2}{*}{$<0.001$} & 0.72 & 0.99 & \multirow[t]{2}{*}{0.001} \\
\hline & $\begin{array}{l}(0.63- \\
0.33)\end{array}$ & $(0.57-1)$ & $\begin{array}{l}(1.14- \\
2.37)\end{array}$ & & $\begin{array}{l}(0.58- \\
1.05)\end{array}$ & $\begin{array}{l}(1.11- \\
2.14)\end{array}$ & & $\begin{array}{l}(0.55- \\
0.95)\end{array}$ & $\begin{array}{l}(0.8- \\
1.3)\end{array}$ & \\
\hline
\end{tabular}

\begin{tabular}{|c|c|c|c|c|c|c|c|c|c|c|}
\hline CRP mg/L & 61 & 45.9 & 134 & $<0.001$ & 47.5 & 134 & $<0.001$ & 35 & 90 & $<0.001$ \\
\hline (median, Q1-Q3) & $\begin{array}{l}(24- \\
125)\end{array}$ & $(14-86)$ & $\begin{array}{l}(72- \\
207)\end{array}$ & & $\begin{array}{l}(15.2- \\
93)\end{array}$ & $\begin{array}{l}(68- \\
211)\end{array}$ & & $\begin{array}{l}(10- \\
75)\end{array}$ & $\begin{array}{l}(48- \\
151)\end{array}$ & \\
\hline
\end{tabular}

\begin{tabular}{|c|c|c|c|c|c|c|c|c|c|c|}
\hline \multirow{3}{*}{$\begin{array}{l}\text { PCT ng/mL } \\
\text { (median, Q1-Q3) }\end{array}$} & 0.08 & 0.06 & 0.18 & $<0.001$ & 0.06 & 0.19 & $<0.001$ & 0.05 & 0.09 & 0.001 \\
\hline & $\begin{array}{l}(0.04- \\
0.2)\end{array}$ & $\begin{array}{l}(0.03- \\
0.13)\end{array}$ & $\begin{array}{l}(0.1- \\
0.4)\end{array}$ & & $\begin{array}{l}(0.03- \\
0.13)\end{array}$ & $\begin{array}{l}(0.1- \\
0.6)\end{array}$ & & $\begin{array}{l}(0.03- \\
0.1)\end{array}$ & $\begin{array}{l}(0.06- \\
0.2)\end{array}$ & \\
\hline & (N 290) & (N 196) & (N 94) & & $\begin{array}{l}(\mathrm{N} \\
205)\end{array}$ & (N 85) & & $\begin{array}{l}(\mathrm{N} \\
150)\end{array}$ & $\begin{array}{l}(\mathrm{N} \\
55)\end{array}$ & \\
\hline
\end{tabular}

\begin{tabular}{|c|c|c|c|c|c|c|c|c|c|c|}
\hline \multirow{3}{*}{$\begin{array}{l}\text { D-dimer ng/mL, } \\
\text { (median, Q1-Q3) }\end{array}$} & 753 & 647 & 1295 & \multirow[t]{3}{*}{$<0.001$} & 669 & 1212 & \multirow[t]{3}{*}{$<0.001$} & 603 & 829 & \multirow[t]{3}{*}{0.009} \\
\hline & $\begin{array}{l}(446- \\
1437)\end{array}$ & $\begin{array}{l}(411- \\
1063)\end{array}$ & $\begin{array}{l}(700- \\
2365)\end{array}$ & & $\begin{array}{l}(417- \\
1148)\end{array}$ & $\begin{array}{l}(658- \\
2102)\end{array}$ & & $\begin{array}{l}(408- \\
999)\end{array}$ & $\begin{array}{l}(508- \\
1666)\end{array}$ & \\
\hline & (N 315) & (N 219) & (N 96) & & $\begin{array}{l}(\mathrm{N} \\
229)\end{array}$ & $(\mathrm{N} 86)$ & & $\begin{array}{l}(\mathrm{N} \\
172)\end{array}$ & $\begin{array}{l}(\mathrm{N} \\
57)\end{array}$ & \\
\hline
\end{tabular}

\begin{tabular}{|c|c|c|c|c|c|c|c|c|c|c|}
\hline LDH UI/L & 349 & 323 & 456 & $<0.001$ & 323 & 494 & $<0.001$ & 303 & 395 & $<0.001$ \\
\hline \multirow[t]{2}{*}{ (median, Q1-Q3) } & $\begin{array}{l}(268- \\
487)\end{array}$ & $\begin{array}{l}(249- \\
432)\end{array}$ & $\begin{array}{l}(323- \\
597)\end{array}$ & & $\begin{array}{l}(244- \\
427)\end{array}$ & $\begin{array}{l}(343- \\
616)\end{array}$ & & $\begin{array}{l}(233- \\
413)\end{array}$ & $\begin{array}{l}(295- \\
500)\end{array}$ & \\
\hline & (N 315) & (N 218) & (N 97) & & $\begin{array}{l}(\mathrm{N} \\
228)\end{array}$ & (N 87) & & $\begin{array}{l}(\mathrm{N} \\
171)\end{array}$ & $\begin{array}{l}(\mathrm{N} \\
57)\end{array}$ & \\
\hline
\end{tabular}

Data are presented as median [first quartile (Q1)-third quartile (Q3)].The Mann-Whitney U test was used to determine significance between biomarker concentrations. CRP, C-reactive protein; MR-proADM, mid-regional proadrenomedullin; PCT, procalcitonin; LDH, lactate dehydrogenase.

IMV: Invasive mechanical ventilation

NIMV: Non Invasive mechanical ventilation

Table 3. Univariable Cox Regression Analysis for biomarkers and clinical characteristics for the primary (survivors) and for the secondary (IMV, NIMV) outcomes Univariate Cox Regression Analysis for the prediction of 45-day mortality and 28-day IMV/NIMV 


\begin{tabular}{|c|c|c|c|c|c|c|c|c|c|c|}
\hline $\begin{array}{l}\text { Cut- } \\
\text { off }\end{array}$ & $\begin{array}{l}\text { Overall } \\
(\mathrm{N})\end{array}$ & $\begin{array}{l}\text { Non- } \\
\text { Surviv } \\
\text { (N) }\end{array}$ & $\begin{array}{l}P \\
\text { value }\end{array}$ & $\begin{array}{l}\text { HROverall } \\
(95 \% \text { IC) } \\
(\mathrm{N})\end{array}$ & $\begin{array}{l}\text { IMV } \\
(\mathrm{N})\end{array}$ & $\begin{array}{l}P \\
\text { value }\end{array}$ & $\begin{array}{l}\text { HROverall } \\
(95 \% \text { IC) } \\
(\mathrm{N})\end{array}$ & $\begin{array}{l}\text { NIMV } \\
(\mathrm{N})\end{array}$ & $\begin{array}{l}P \\
\text { value }\end{array}$ & $\begin{array}{l}\text { HR } \\
(95 \% \\
\text { IC) }\end{array}$ \\
\hline
\end{tabular}

\begin{tabular}{|c|c|c|c|c|c|c|c|c|c|c|}
\hline Age & 320 & 96 & $<0.001$ & $\begin{array}{l}1.06 \\
321 \\
(1.04- \\
1.07)\end{array}$ & 87 & $<0.001$ & $\begin{array}{l}1.03234 \\
(1.01- \\
1.04)\end{array}$ & 57 & 0.003 & $\begin{array}{l}1.03 \\
(1.01- \\
1.04)\end{array}$ \\
\hline \multirow[t]{2}{*}{ Gender } & 320 & 96 & 0.182 & 1.35321 & 87 & 0.007 & 2.03234 & 57 & 0.301 & 1.34 \\
\hline & & & & $\begin{array}{l}(0.87- \\
2.11)\end{array}$ & & & $\begin{array}{l}(1.21- \\
3.41)\end{array}$ & & & $\begin{array}{l}(0.77- \\
2.35)\end{array}$ \\
\hline
\end{tabular}

Hypertension

$320 \quad 96 \quad<0.001$

$2.87321 \quad 87 \quad<0.001$

2.16234

57

0.002

2.28

$(1.90-$

(1.41-

3.31)

(1.35-

3.8)

\begin{tabular}{|c|c|c|c|c|c|c|c|c|c|c|}
\hline \multirow[t]{2}{*}{ Diabetes } & 320 & 96 & $<0.001$ & 2.43321 & 87 & $<0.001$ & 2.41234 & 57 & 0.137 & 1.76 \\
\hline & & & & $\begin{array}{l}(1.51- \\
3.92)\end{array}$ & & & $\begin{array}{l}(1.48- \\
3.95)\end{array}$ & & & $\begin{array}{l}(0.84 \\
3.73)\end{array}$ \\
\hline
\end{tabular}

\begin{tabular}{|c|c|c|c|c|c|c|c|c|c|c|}
\hline $\begin{array}{l}\text { Respiratory } \\
\text { disease }\end{array}$ & 320 & 96 & 0.017 & $\begin{array}{l}2.0321 \\
(1.13- \\
3.52)\end{array}$ & 87 & 0.038 & $\begin{array}{l}1.91234 \\
(1.04- \\
3.51)\end{array}$ & 57 & 0.669 & $\begin{array}{l}0.77 \\
(0.24- \\
2.49)\end{array}$ \\
\hline
\end{tabular}

\begin{tabular}{|c|c|c|c|c|c|c|c|c|c|c|}
\hline \multirow[t]{2}{*}{ Malignancy } & 320 & 96 & 0.057 & 1.95321 & 87 & 0.115 & 1.8234 & 57 & 0.298 & 1.72 \\
\hline & & & & $\begin{array}{l}(0.98- \\
3.87)\end{array}$ & & & $\begin{array}{l}(0.87- \\
3.72)\end{array}$ & & & $\begin{array}{l}(0.62 \\
4.74)\end{array}$ \\
\hline
\end{tabular}

\begin{tabular}{|c|c|c|c|c|c|c|c|c|c|c|}
\hline $\begin{array}{l}\text { Cardiovascular } \\
\text { disease }\end{array}$ & 320 & 96 & $<0.001$ & $\begin{array}{l}2.47321 \\
(1.60- \\
3.84)\end{array}$ & 87 & 0.307 & $\begin{array}{l}1.31234 \\
(0.78- \\
2.20)\end{array}$ & 57 & 0.385 & $\begin{array}{l}1.34 \\
(0.70- \\
2.59)\end{array}$ \\
\hline
\end{tabular}

\begin{tabular}{|c|c|c|c|c|c|c|c|c|c|c|}
\hline Renal disease & 320 & 96 & $<0.001$ & $\begin{array}{c}5.44 \\
321 \\
(3.59- \\
8.25)\end{array}$ & 87 & $<0.001$ & $\begin{array}{l}4.85234 \\
(3.14- \\
7.50)\end{array}$ & 57 & 0.003 & $\begin{array}{l}2.92 \\
(1.43 \\
5.97)\end{array}$ \\
\hline
\end{tabular}




\begin{tabular}{|c|c|c|c|c|c|c|c|c|c|c|c|}
\hline Obesity & & 320 & 96 & 0.200 & $\begin{array}{l}1.65 \\
321 \\
(0.77- \\
3.57)\end{array}$ & 87 & 0.007 & $\begin{array}{l}2.74234 \\
(1.32- \\
5.67)\end{array}$ & 57 & 0.353 & $\begin{array}{l}0.05 \\
(0- \\
29.60)\end{array}$ \\
\hline $\begin{array}{l}\text { MR-pro ADM } \\
\text { (nmol/L) }\end{array}$ & 1.105 & 320 & 96 & $<0.001$ & $\begin{array}{l}9.10321 \\
(5.64- \\
14.7)\end{array}$ & 87 & $<0.001$ & $\begin{array}{l}7.22234 \\
(4.41- \\
11.83)\end{array}$ & 57 & $<0.001$ & $\begin{array}{l}4.2 \\
(2.20- \\
8.0)\end{array}$ \\
\hline CRP (mg/L) & 95.5 & 320 & 96 & $<0.001$ & $\begin{array}{l}6.28 \\
321 \\
(4.03- \\
9.78)\end{array}$ & 87 & $<0.001$ & $\begin{array}{l}4.79234 \\
(3.05- \\
7.52)\end{array}$ & 57 & $<0.001$ & $\begin{array}{l}4.2 \\
(2.40- \\
7.50)\end{array}$ \\
\hline РCT (ng/mL) & 0.095 & 289 & 93 & 0.001 & $\begin{array}{l}4.62 \\
290 \\
(2.86- \\
7.45)\end{array}$ & 85 & $<0.001$ & $\begin{array}{l}5.07205 \\
(3.01- \\
8.54)\end{array}$ & 55 & $<0.001$ & $\begin{array}{l}3.1 \\
(1.70- \\
5.80)\end{array}$ \\
\hline $\begin{array}{l}\text { D-dimer } \\
\text { (ng/mL) }\end{array}$ & 985 & 314 & 95 & $<0.001$ & $\begin{array}{l}4.18315 \\
(2.72- \\
6.43)\end{array}$ & 86 & $<0.001$ & $\begin{array}{l}3.22229 \\
(2.08- \\
5.01)\end{array}$ & 57 & 0.002 & $\begin{array}{l}2.3 \\
(1.40- \\
4.0)\end{array}$ \\
\hline LDH (UI/L) & 439.5 & 314 & 96 & $<0.001$ & $\begin{array}{l}3.52 \\
\quad 315 \\
(2.35- \\
5.27)\end{array}$ & 87 & $<0.001$ & $\begin{array}{l}4.47228 \\
(2.90- \\
6.91)\end{array}$ & 57 & $<0.001$ & $\begin{array}{l}2.8 \\
(1.60- \\
4.80)\end{array}$ \\
\hline
\end{tabular}

$\mathrm{Cl}$, confidence interval; CRP, C-reactive protein;HR, hazard ratio; IQR, interquartilerange; MR-proADM, mid-regional proadrenomedullin; PCT procalcitonin; LDH, lactate dehydrogenase.

Biomarkers cut-off values derived from ROC (Receiver Operating Characteristic) using the Youden index.

IMV: Invasive mechanical ventilation curve analysis

NIVM: Non Invasive Mechanical Ventilation

Table 4. Multivariable Cox Regression Analysis pooling together biomarkers and clinical characteristics for the primary (survivors) and for the secondary (IMV, NIM) Multivariate Cox Regression Analysis for the prediction of 45-day mortality and 28-day IMV/NIMV 


\begin{tabular}{|c|c|c|c|c|c|c|c|c|c|c|c|}
\hline $\begin{array}{l}\text { Overall } \\
\text { (N) }\end{array}$ & $\begin{array}{l}\text { Non } \\
\text { Surviv } \\
\text { (N) }\end{array}$ & $\begin{array}{c}\mathrm{P} \\
\text { value }\end{array}$ & $\begin{array}{l}\text { HR } \\
(95 \% \\
\text { IC) }\end{array}$ & $\begin{array}{l}\text { Overall } \\
(\mathrm{N})\end{array}$ & $\begin{array}{l}\text { IMV } \\
(\mathrm{N})\end{array}$ & $\begin{array}{c}P \\
\text { value }\end{array}$ & $\begin{array}{l}\text { HR } \\
(95 \% \\
\text { IC) }\end{array}$ & $\begin{array}{l}\text { Overall } \\
(\mathrm{N})\end{array}$ & $\begin{array}{l}\text { NIMV } \\
(\mathrm{N})\end{array}$ & $\begin{array}{l}\mathrm{P} \\
\text { value }\end{array}$ & $\begin{array}{l}\text { HR } \\
\text { (95\% } \\
\text { IC) }\end{array}$ \\
\hline
\end{tabular}

\begin{tabular}{|c|c|c|c|c|c|c|c|c|c|c|c|c|}
\hline Age & 284 & 93 & 0.083 & 1.02 & 285 & 85 & 0.386 & 0.99 & 200 & 55 & 0.952 & 0.99 \\
\hline & & & & $\begin{array}{l}(0.99 \\
1.04)\end{array}$ & & & & $\begin{array}{l} \\
(0.97 \\
1.01)\end{array}$ & & & & $\begin{array}{l}(0.97 \\
1.02)\end{array}$ \\
\hline
\end{tabular}

\begin{tabular}{|c|c|c|c|c|c|c|c|c|c|c|c|c|}
\hline \multirow[t]{2}{*}{ Gender } & & & & & \multirow[t]{2}{*}{285} & \multirow[t]{2}{*}{85} & \multirow[t]{2}{*}{0.095} & \multicolumn{5}{|l|}{1.63} \\
\hline & & & & & & & & $\begin{array}{l}(0.92- \\
2.89)\end{array}$ & & & & \\
\hline \multirow[t]{2}{*}{ Hypertension } & 284 & 93 & 0.97 & 1.01 & 285 & 85 & 0.93 & 1.02 & 200 & 55 & 0.45 & 1.3 \\
\hline & & & & $\begin{array}{l}(0.63- \\
1.61)\end{array}$ & & & & $\begin{array}{l}(0.64- \\
1.64)\end{array}$ & & & & $\begin{array}{l}(0.70- \\
2.30)\end{array}$ \\
\hline
\end{tabular}

\begin{tabular}{|c|c|c|c|c|c|c|c|c|}
\hline Diabetes & 284 & 93 & 0.88 & $\begin{array}{l}1.04 \\
(0.61- \\
1.80)\end{array}$ & 285 & 85 & 0.292 & $\begin{array}{l}1.34 \\
(0.78- \\
2.31)\end{array}$ \\
\hline $\begin{array}{l}\text { Respiratory } \\
\text { disease }\end{array}$ & 284 & 93 & 0.047 & $\begin{array}{l}1.86 \\
(1.01- \\
3.41)\end{array}$ & 285 & 85 & 0.248 & $\begin{array}{l}1.49 \\
(0.76- \\
2.94)\end{array}$ \\
\hline
\end{tabular}

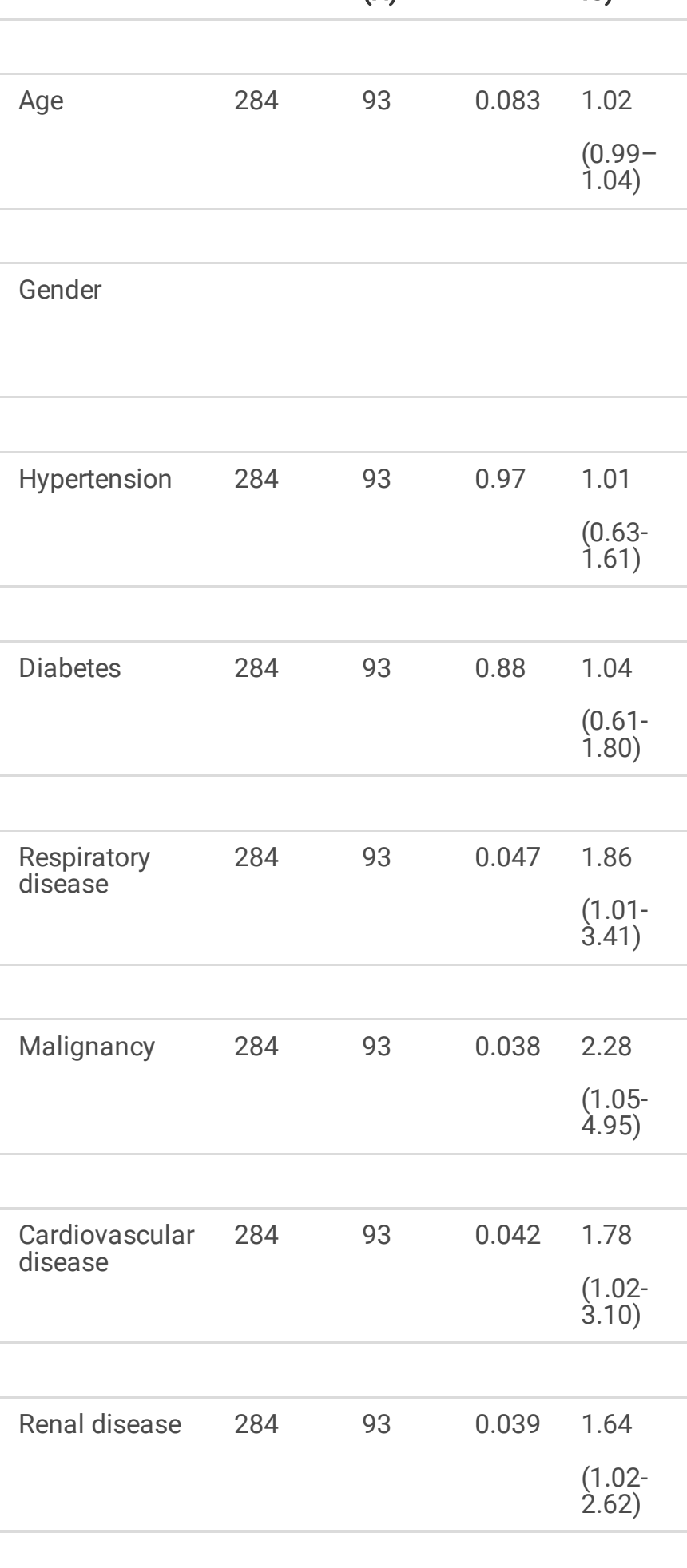

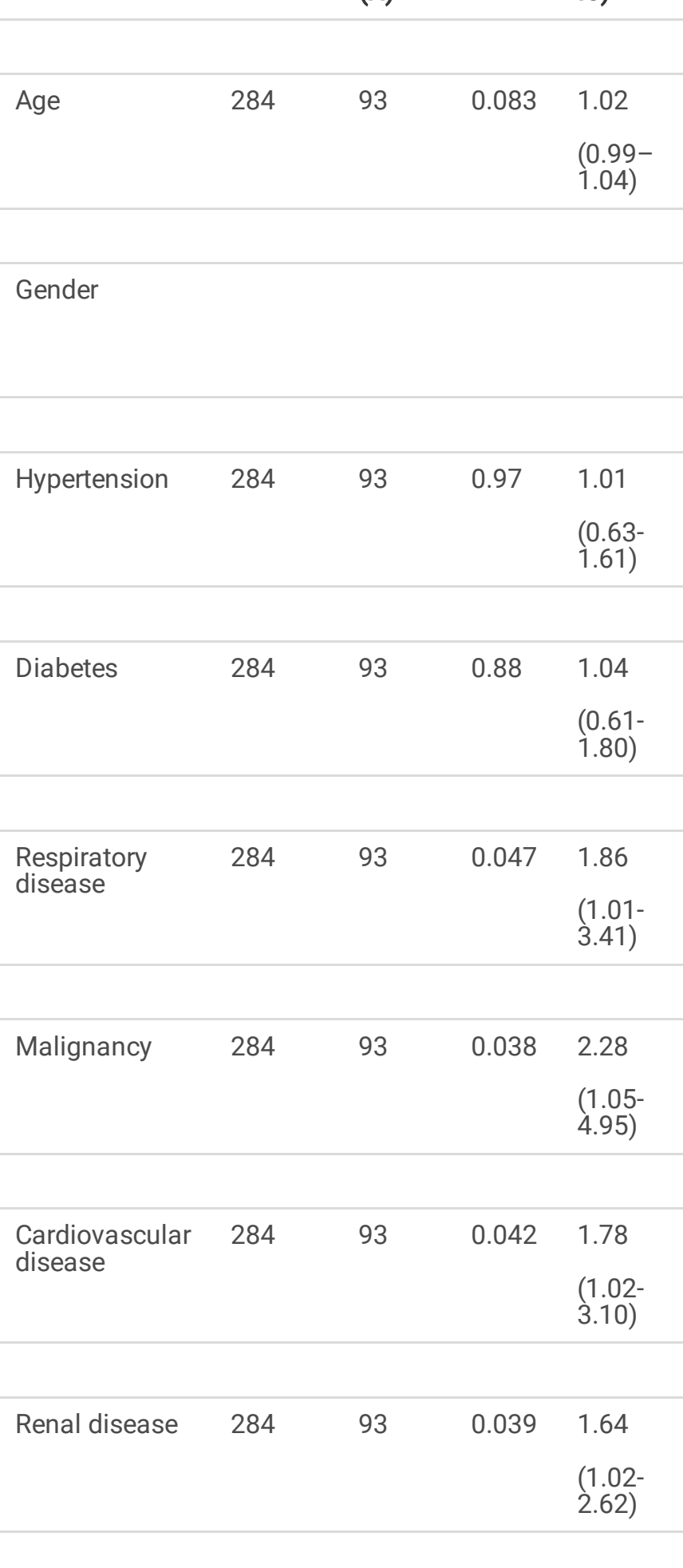

\begin{tabular}{|c|c|c|c|c|c|c|c|c|c|c|c|c|}
\hline \multirow[t]{2}{*}{ Renal disease } & 284 & 93 & 0.039 & 1.64 & 285 & 85 & 0.019 & 1.82 & 200 & 55 & 0.745 & 1.1 \\
\hline & & & & $\begin{array}{l}(1.02- \\
2.62)\end{array}$ & & & & $\begin{array}{l}(1.10- \\
3.0)\end{array}$ & & & & $\begin{array}{l}(0.50- \\
2.40)\end{array}$ \\
\hline
\end{tabular}

Obesity

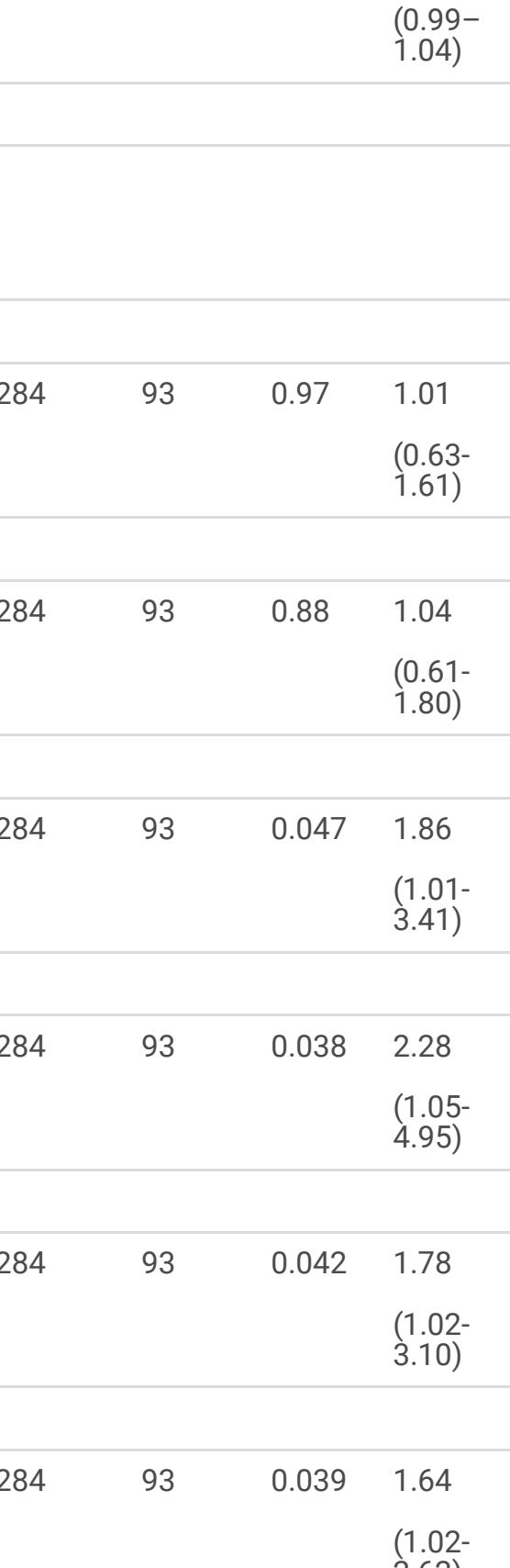

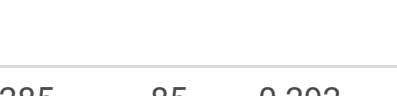

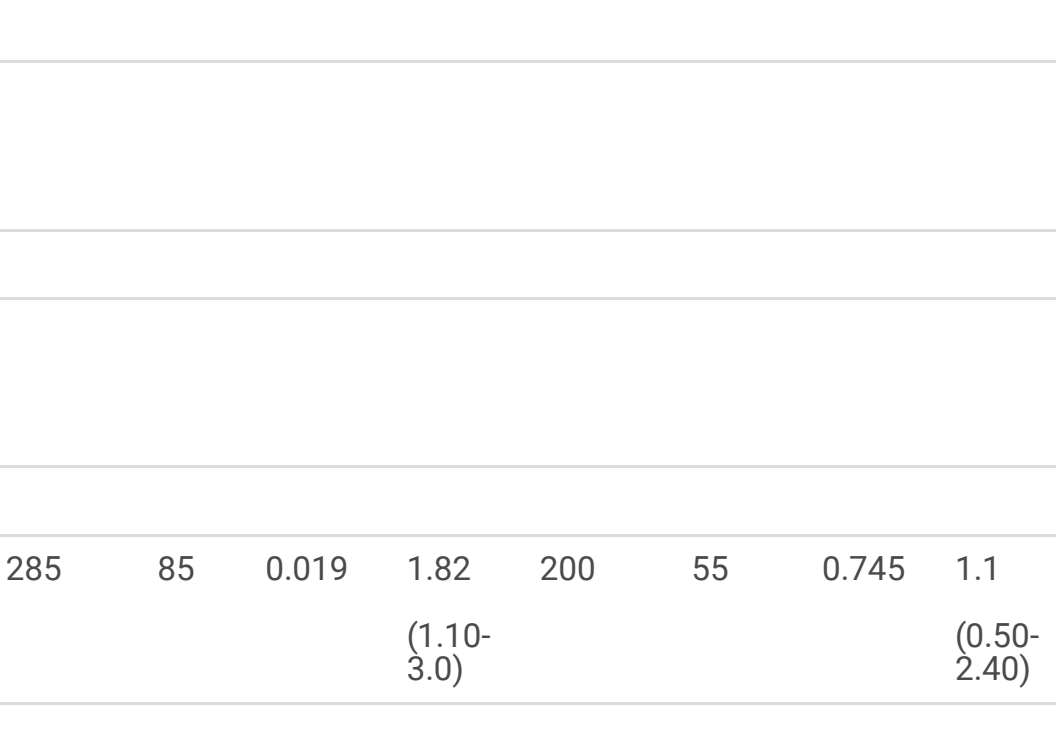

Gende

(1.64)

$\begin{aligned} 285 \quad 85 \quad 0.259 \quad & 1.62 \\ & (0.70- \\ & 3.75)\end{aligned}$

\begin{tabular}{|c|c|c|c|c|c|c|c|c|c|c|c|c|}
\hline $\begin{array}{l}\text { MR-pro ADM } \\
\text { (nmol/L) }\end{array}$ & 284 & 93 & $<.001$ & $\begin{array}{l}2.97 \\
(1.70- \\
5.28)\end{array}$ & 285 & 85 & 0.001 & $\begin{array}{l}2.83 \\
(1.49- \\
5.36)\end{array}$ & 200 & 55 & 0.071 & $\begin{array}{l}2.0 \\
(0.90- \\
4.30)\end{array}$ \\
\hline
\end{tabular}




\begin{tabular}{|c|c|c|c|c|c|c|c|c|c|c|c|c|}
\hline $\mathrm{CRP}(\mathrm{mg} / \mathrm{L})$ & 284 & 93 & $\begin{array}{l}<.001 \\
0.00\end{array}$ & $\begin{array}{l}2.85 \\
(1.73- \\
4.69)\end{array}$ & 285 & 85 & 0.106 & $\begin{array}{l}1.54 \\
(0.91- \\
2.6)\end{array}$ & 200 & 55 & 0.036 & $\begin{array}{l}2.0 \\
(1.0- \\
3.70)\end{array}$ \\
\hline \multirow[t]{2}{*}{ РСТ (ng/mL) } & 284 & 93 & 0.602 & 1.17 & 285 & 85 & 0.288 & 1.41 & 200 & 55 & 0.075 & 1.8 \\
\hline & & & & $\begin{array}{l}(0.65- \\
2.10)\end{array}$ & & & & $\begin{array}{l}(0.75- \\
2.65)\end{array}$ & & & & $\begin{array}{l}(0.90- \\
3.60)\end{array}$ \\
\hline \multirow{2}{*}{$\begin{array}{l}\text { D-dimer } \\
\text { (ng/mL) }\end{array}$} & 284 & 93 & 0.024 & 1.8 & 285 & 85 & 0.085 & 1.56 & 200 & 55 & 0.169 & 1.5 \\
\hline & & & & $\begin{array}{l}(1.08- \\
2.99)\end{array}$ & & & & $\begin{array}{l}(0.94- \\
2.59)\end{array}$ & & & & $\begin{array}{l}(0.80- \\
2.80)\end{array}$ \\
\hline \multirow[t]{2}{*}{ LDH (UI/L) } & 284 & 93 & 0.047 & 1.7 & 285 & 85 & 0.002 & 2.18 & 200 & 55 & 0.078 & 1.7 \\
\hline & & & & $\begin{array}{l}(1.01- \\
2.84)\end{array}$ & & & & $\begin{array}{l}(1.33- \\
3.57)\end{array}$ & & & & $\begin{array}{l}(0.90- \\
3.10)\end{array}$ \\
\hline
\end{tabular}

Age, Hpertension, Diabetes, Respiratory disease, Malignancy, Cardiovascular disease and Renal disease were used as Adjustingvariables within the Multivariate

Cox Regression Analysis for the prediction of 45-day mortality.

Age, Gender, Hpertension, Diabetes, Respiratory disease and renal disease were used as adjusting variables within the MultivariateCox Regression Analysis for the prediction of 28-day IMV.

Age, Hypertension and Renal disease were used as adjusting variables within the Multivariate Cox Regression Analysis for theprediction of 28-day IMV.

MR-proADM, mid-regional proadrenomedullin; CRP, C-reactive protein; PCT procalcitonin; LDH, lactate dehydrogenase

Table 5. Prognostic accuracy of biomarkers for different outcomes 


\begin{tabular}{|c|c|c|c|c|c|c|c|c|c|c|c|}
\hline & Outcome & $\begin{array}{l}\text { AUC } \\
(95 \% \\
\text { Cl) }\end{array}$ & $\begin{array}{l}\text { Cut- } \\
\text { off }\end{array}$ & $\begin{array}{l}\mathrm{P} \\
\text { value }\end{array}$ & $\begin{array}{l}\text { Sensitivity } \\
(95 \% \mathrm{Cl})\end{array}$ & $\begin{array}{l}\text { Specificity } \\
(95 \% \mathrm{Cl})\end{array}$ & $\begin{array}{l}\text { PPV } \\
(95 \% \\
\text { Cl) }\end{array}$ & $\begin{array}{l}\text { NPV } \\
(95 \% \\
\text { Cl) }\end{array}$ & $\begin{array}{l}\text { LR+ } \\
(95 \% \\
\text { Cl) }\end{array}$ & $\begin{array}{l}\text { LR- } \\
(95 \% \\
\text { Cl) }\end{array}$ & $\begin{array}{l}\text { OR } \\
(95 \% \\
\text { Cl) }\end{array}$ \\
\hline & Mortality & 0.848 & 1.105 & & 0.77 & 0.80 & 0.65 & 0.87 & 3.75 & 0.29 & 12.76 \\
\hline & & $\begin{array}{l}(0.80- \\
0.90)\end{array}$ & & & $\begin{array}{l}(0.67- \\
0.85)\end{array}$ & $\begin{array}{l}(0.73- \\
0.85)\end{array}$ & $\begin{array}{l}(0.58- \\
0.71)\end{array}$ & $\begin{array}{l}(0.83- \\
0.91)\end{array}$ & $\begin{array}{l}(2.8- \\
5.1)\end{array}$ & $\begin{array}{l}(0.2- \\
0.4)\end{array}$ & $\begin{array}{l}(7.05- \\
23.08)\end{array}$ \\
\hline \multirow{6}{*}{$\begin{array}{l}\text { MR-proADM } \\
(\mathrm{nmol} / \mathrm{L})\end{array}$} & IMV & 0,807 & 1.105 & & 0.75 & 0.77 & 0.58 & 0.88 & 3.2 & 0.32 & 9.92 \\
\hline & & $\begin{array}{l}(0.75- \\
0.86)\end{array}$ & & & $\begin{array}{l}(0.65- \\
0.84)\end{array}$ & $\begin{array}{l}(0.70- \\
0.82)\end{array}$ & $\begin{array}{l}(0.51- \\
0.64)\end{array}$ & $\begin{array}{l}(0.83- \\
0.91)\end{array}$ & $\begin{array}{l}(2.43- \\
4.23)\end{array}$ & $\begin{array}{l}(0.22- \\
0.47)\end{array}$ & $\begin{array}{l}(5.5- \\
17.92)\end{array}$ \\
\hline & NIMV & 0.707 & 0.785 & & 0.80 & 0.55 & 0.40 & 0.88 & 1.76 & 0.37 & 4.79 \\
\hline & & $\begin{array}{l}(0.63- \\
0.78)\end{array}$ & & & 0.67-0.90) & $\begin{array}{l}(0.46- \\
0.63)\end{array}$ & $\begin{array}{l}(0.35- \\
0.45)\end{array}$ & $\begin{array}{l}(0.81- \\
0.93)\end{array}$ & $\begin{array}{l}(1.41- \\
2.19)\end{array}$ & $\begin{array}{l}(0.21- \\
0.64)\end{array}$ & $\begin{array}{l}(2.29- \\
10.0)\end{array}$ \\
\hline & Mortality & 0.785 & 95.5 & 0.09 & 0.71 & 0.78 & 0.62 & 0.85 & 3.24 & 0.37 & 8.8 \\
\hline & & $\begin{array}{l}(0.73- \\
0.84)\end{array}$ & & & $\begin{array}{l}(0.61- \\
0.80)\end{array}$ & $\begin{array}{l}(0.72- \\
0.84)\end{array}$ & $\begin{array}{l}(0.55- \\
0.68)\end{array}$ & $\begin{array}{l}(0.80- \\
0.88)\end{array}$ & $\begin{array}{l}(2.4- \\
4.4)\end{array}$ & $\begin{array}{l}(0.3- \\
0.5)\end{array}$ & $\begin{array}{l}(5.01- \\
15.5)\end{array}$ \\
\hline \multirow[t]{6}{*}{ CRP (mg/L) } & IMV & 0.759 & 95.5 & 0.242 & 0.67 & 0.74 & 0.52 & 0.84 & 2.58 & 0.45 & 5.79 \\
\hline & & $\begin{array}{l}(0.70- \\
0.82)\end{array}$ & & & $\begin{array}{l}(0.56- \\
0.77)\end{array}$ & $\begin{array}{l}(0.67- \\
0.80)\end{array}$ & $\begin{array}{l}(0.45- \\
0.59)\end{array}$ & $\begin{array}{l}(0.79- \\
0.88)\end{array}$ & $\begin{array}{l}(1.95- \\
3.40)\end{array}$ & $\begin{array}{l}(0.33- \\
0.61)\end{array}$ & $\begin{array}{l}(3.34- \\
10.06)\end{array}$ \\
\hline & NIMV & 0.709 & 59.5 & 0.97 & 0.69 & 0.67 & 0.44 & 0.85 & 2.09 & 0.46 & 4.52 \\
\hline & & $\begin{array}{l}(0.63- \\
0.79)\end{array}$ & & & $\begin{array}{l}(0.55- \\
0.81)\end{array}$ & $\begin{array}{l}(0.59- \\
0.75)\end{array}$ & $\begin{array}{l}(0.37- \\
0.51)\end{array}$ & $\begin{array}{l}(0.79- \\
0.90)\end{array}$ & $\begin{array}{l}(1.56- \\
2.79)\end{array}$ & $\begin{array}{l}(0.31- \\
0.70)\end{array}$ & $\begin{array}{l}(2.32- \\
8.81)\end{array}$ \\
\hline & Mortality & 0.759 & 0.095 & 0.021 & 0.77 & 0.67 & 0.53 & 0.85 & 2.29 & 0.35 & 6.5 \\
\hline & & $\begin{array}{l}(0.70- \\
0.82)\end{array}$ & & & 0.67-0.85) & $(0.6-0.73)$ & $\begin{array}{l}(0.47- \\
0.59)\end{array}$ & $\begin{array}{l}(0.80- \\
0.89)\end{array}$ & $\begin{array}{l}(1.8- \\
2.9)\end{array}$ & $\begin{array}{l}(0.2- \\
0.5)\end{array}$ & $\begin{array}{l}(3.7- \\
11.42)\end{array}$ \\
\hline \multirow[t]{6}{*}{ PCT (ng/ml) } & IMV & 0.769 & 0.095 & 0.354 & 0.79 & 0.66 & 0.49 & 0.88 & 2.28 & 0.32 & 7.07 \\
\hline & & $\begin{array}{l}(0.71- \\
0.83)\end{array}$ & & & $\begin{array}{l}(0.69- \\
0.87)\end{array}$ & $\begin{array}{l}(0.59- \\
0.72)\end{array}$ & $\begin{array}{l}(0.44- \\
0.55)\end{array}$ & $\begin{array}{l}(0.83- \\
0.92)\end{array}$ & $\begin{array}{l}(1.83- \\
2.85)\end{array}$ & $\begin{array}{l}(0.21- \\
0.49)\end{array}$ & $\begin{array}{l}(3.89- \\
12.83)\end{array}$ \\
\hline & NIMV & 0.657 & 0.055 & 0.38 & 0.76 & 0.55 & 0.39 & 0.86 & 1.68 & 0.43 & 3.87 \\
\hline & & $\begin{array}{l}(0.57- \\
0.74)\end{array}$ & & & $\begin{array}{l}(0.63- \\
0.87)\end{array}$ & $\begin{array}{l}(0.46- \\
0.63)\end{array}$ & $\begin{array}{l}(0.34- \\
0.45)\end{array}$ & $\begin{array}{l}(0.79- \\
0.91)\end{array}$ & $\begin{array}{l}(1.33- \\
2.11)\end{array}$ & $\begin{array}{l}(0.26- \\
0.71)\end{array}$ & $\begin{array}{l}(1.92- \\
7.81)\end{array}$ \\
\hline & Mortality & 0.705 & 985.5 & 0.0006 & 0.67 & 0.73 & 0.55 & 0.82 & 2.46 & 0.45 & 5.43 \\
\hline & & $\begin{array}{l}(0.64- \\
0.77)\end{array}$ & & & 0.57-0.76) & $\begin{array}{l}(0.66- \\
0.79)\end{array}$ & $\begin{array}{l}(0.48- \\
0.61)\end{array}$ & $\begin{array}{l}(0.77- \\
0.86)\end{array}$ & $\begin{array}{l}(1.9- \\
3.2)\end{array}$ & $\begin{array}{l}(0.3- \\
0.6)\end{array}$ & $\begin{array}{l}(3.18- \\
9.28)\end{array}$ \\
\hline \multirow{5}{*}{$\begin{array}{l}\text { D-dimer } \\
\text { (ng/mL) }\end{array}$} & IMV & 0.666 & 981.5 & 0.002 & 0.65 & 0.70 & 0.47 & 0.82 & 2.12 & 0.51 & 4.18 \\
\hline & & $\begin{array}{l}(0.60- \\
0.74)\end{array}$ & & & $\begin{array}{l}(0.54- \\
0.75)\end{array}$ & $\begin{array}{l}(0.63- \\
0.76)\end{array}$ & $\begin{array}{l}(0.41- \\
0.54)\end{array}$ & $\begin{array}{l}(0.77- \\
0.86)\end{array}$ & $\begin{array}{l}(1.63- \\
2.76)\end{array}$ & $\begin{array}{l}(0.38- \\
0.69)\end{array}$ & $\begin{array}{l}(2.44- \\
7.15)\end{array}$ \\
\hline & NIMV & 0.610 & 787.5 & 0.11 & 0.60 & 0.66 & 0.40 & 0.81 & 1.74 & 0.61 & 2.85 \\
\hline & & $\begin{array}{l}(0.53- \\
0.70)\end{array}$ & & & $\begin{array}{l}(0.46- \\
0.73)\end{array}$ & $\begin{array}{l}(0.57- \\
0.73)\end{array}$ & $\begin{array}{l}(0.33- \\
0.47)\end{array}$ & $\begin{array}{l}(0.75- \\
0.86)\end{array}$ & $\begin{array}{l}(1.27- \\
2.38)\end{array}$ & $\begin{array}{l}(0.43- \\
0.86)\end{array}$ & $\begin{array}{l}(1.5- \\
5.4)\end{array}$ \\
\hline & Mortality & 0.687 & 439.5 & 0.0001 & 0.55 & 0.80 & 0.57 & 0.78 & 2.71 & 0.56 & 4.83 \\
\hline
\end{tabular}




\begin{tabular}{|c|c|c|c|c|c|c|c|c|c|c|c|}
\hline & & $\begin{array}{l}(0.62- \\
0.76)\end{array}$ & & & $\begin{array}{l}(0.45- \\
0.66)\end{array}$ & $\begin{array}{l}(0.73- \\
0.85)\end{array}$ & $\begin{array}{l}(0.49- \\
0.65)\end{array}$ & $\begin{array}{l}(0.74- \\
0.82)\end{array}$ & $\begin{array}{l}(1.9- \\
3.8)\end{array}$ & $\begin{array}{l}(0.4- \\
0.7)\end{array}$ & $\begin{array}{l}(2.82- \\
8.26)\end{array}$ \\
\hline \multirow[t]{4}{*}{ LDH (UI/L) } & \multirow[t]{2}{*}{ IMV } & 0.736 & 437.5 & 0.101 & 0.61 & 0.80 & 0.56 & 0.83 & 2.98 & 0.49 & 6.30 \\
\hline & & $\begin{array}{l}(0.67- \\
0.80)\end{array}$ & & & $\begin{array}{l}(0.50- \\
0.72)\end{array}$ & $\begin{array}{l}(0.73- \\
0.85)\end{array}$ & $\begin{array}{l}(0.48- \\
0.64)\end{array}$ & $\begin{array}{l}(0.79- \\
0.87)\end{array}$ & $\begin{array}{l}(2.16- \\
4.11)\end{array}$ & $\begin{array}{l}(0.37- \\
0.64)\end{array}$ & $\begin{array}{l}(3.61- \\
11)\end{array}$ \\
\hline & \multirow[t]{2}{*}{ NIMV } & 0.649 & 340.5 & 0.32 & 0.67 & 0.61 & 0.39 & 0.83 & 1.71 & 0.54 & 3.17 \\
\hline & & $\begin{array}{l}(0.56- \\
0.73)\end{array}$ & & & $\begin{array}{l}(0.53- \\
0.79)\end{array}$ & $\begin{array}{l}(0.52- \\
0.69)\end{array}$ & $\begin{array}{l}(0.33- \\
0.46)\end{array}$ & $\begin{array}{l}(0.77- \\
0.88)\end{array}$ & $\begin{array}{l}(1.30- \\
2.25)\end{array}$ & $\begin{array}{l}(0.36- \\
0.81)\end{array}$ & $\begin{array}{l}(1.65- \\
6.11)\end{array}$ \\
\hline
\end{tabular}

AUC analysis for 45-day mortality prediction and for 28-day IMV or NIMV prediction of study population

$P$ value: differences between area of each biomarker vs MR-pro-ADM.

Cut-off derived from ROC (Receiver Operating Characteristic) using the Youden index.

IMV: Invasive Mechanical Ventilation

NIMV: Non Invasive Mechanical Ventilation

MR-proADM, mid-regional proadrenomedullin; CRP, C-reactive protein; PCT procalcitonin; LDH, lactate dehydrogenase.

\section{Figures}



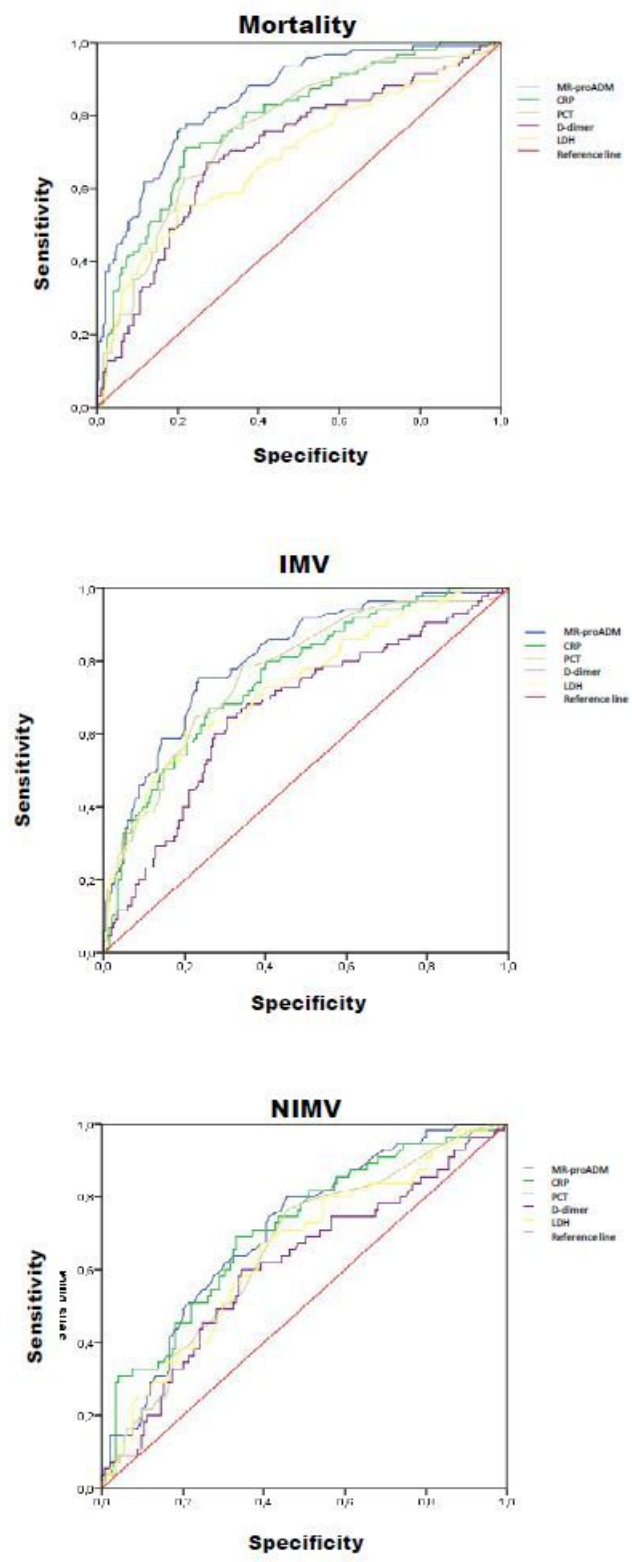

\section{Figure 1}

Association of candidate biomarkers with mortality and mechanical vetilation: AUROC area under the receiver operating characteristic curve. MR-proADM, mid-regional prodrenomedullin; CRP, C-reactive protein; PCT, procalcitonin; LDH, lactate dehydrogenase; IMV, invasive mechanical ventilation; NIMV, non-invasive mechanical ventilation. 

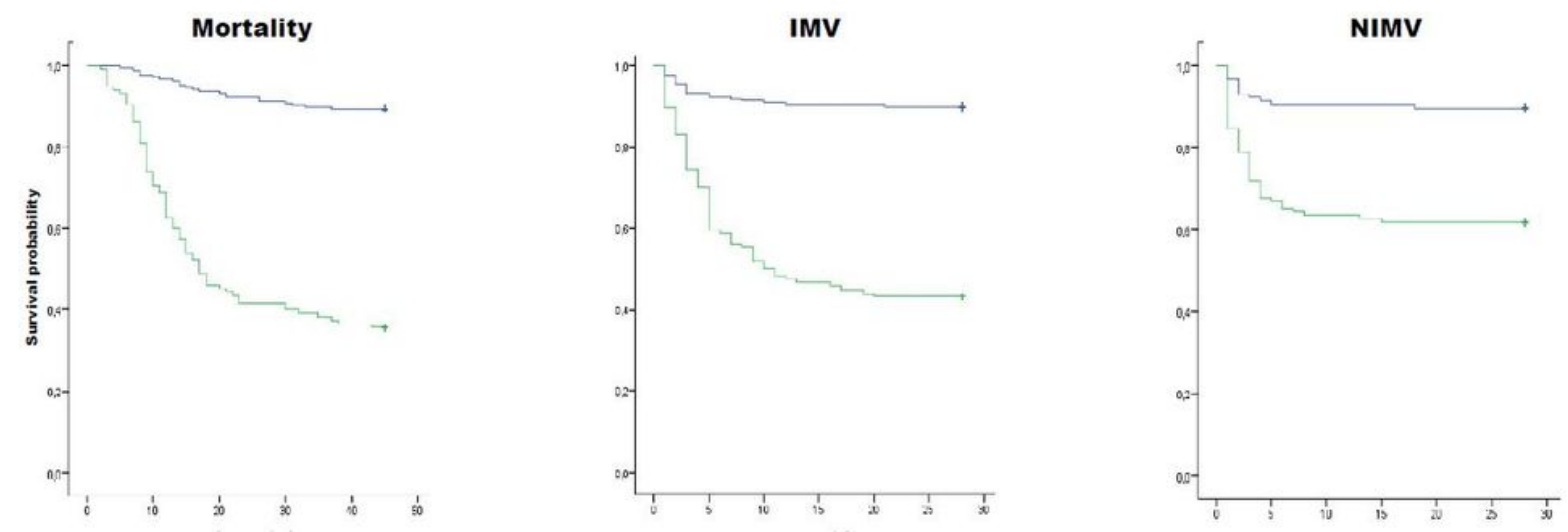

MR-proADM
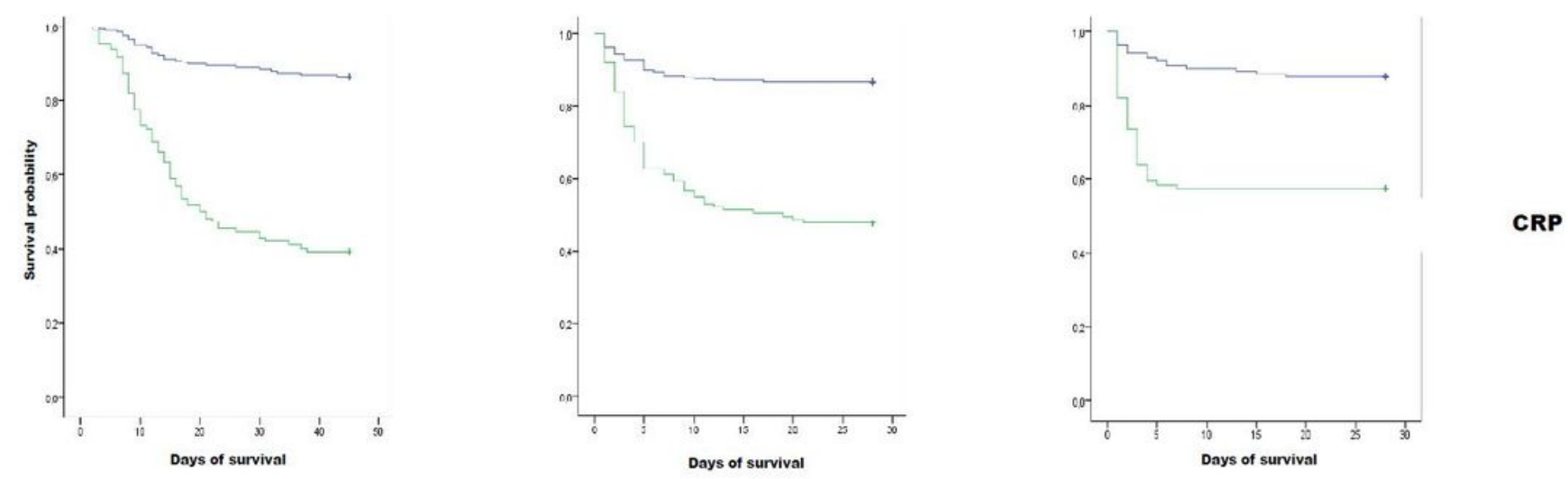

Figure 2

Kaplan-Meier survival curve. Stratification of patients with mid-regional proadrenomedullin (MR-proADM) levels greater or less than $1,105 \mathrm{nmol} / \mathrm{L}$ and C-reactive protein (CRP) levels greater or less than $95,5 \mathrm{mg} / \mathrm{L}$ at admission in the emergency department. IMV, invasive mechanical ventilation; NIMV, non-invasive mechanical ventilation. 

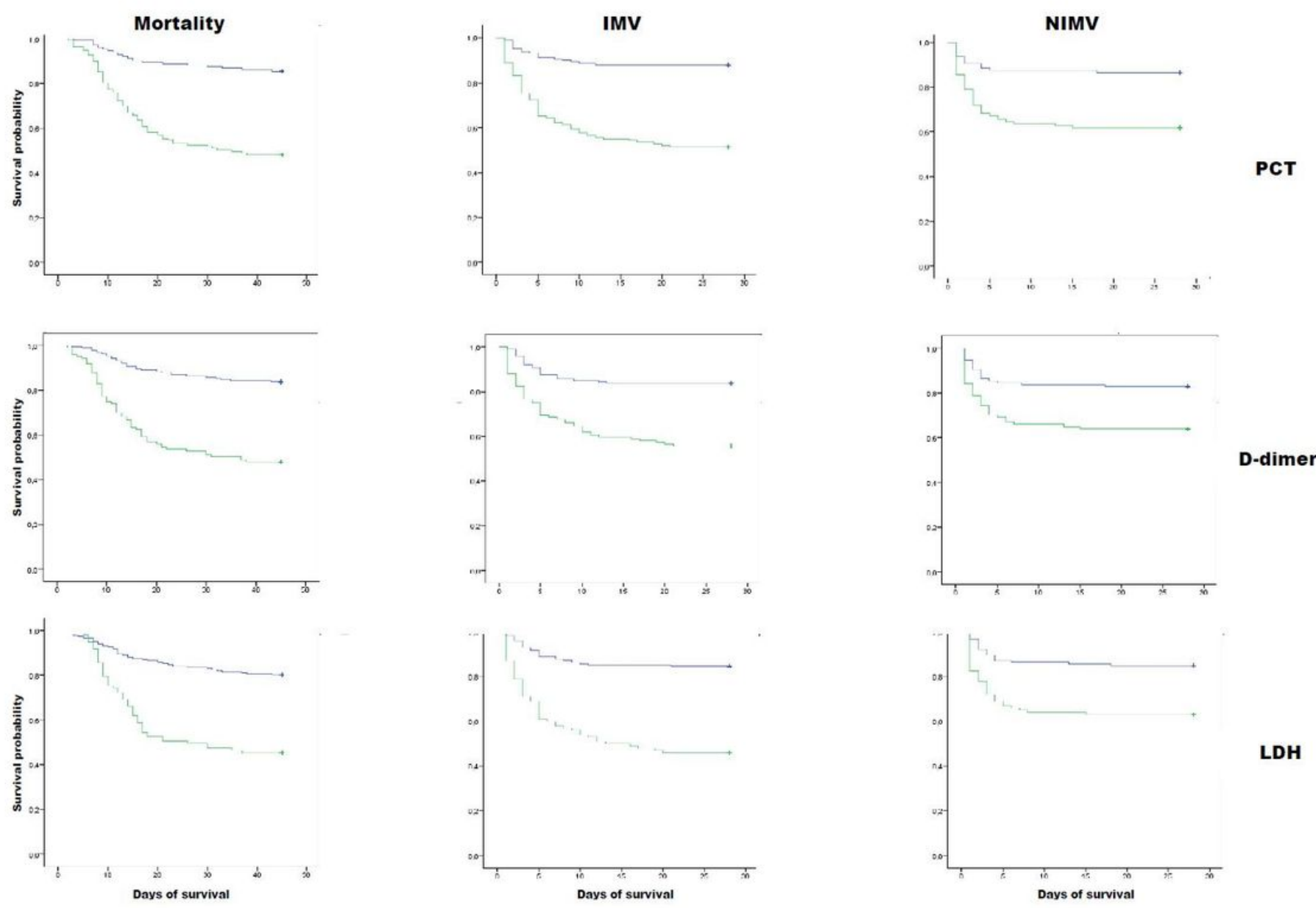

Figure 3

Kaplan-Meier survival curve. Risk stratification of patients with procalcitonin (PCT) levels greater or less than0.095 ng/mL, D-dimer levels greater or less than $985,5 \mathrm{ng} / \mathrm{mL}$ and lactate dehydrogenase (LDH) greater or less than $439,5 \mathrm{U} / \mathrm{L}$ at admission in the emergency department. 